\title{
Characterization and identification of charcoal of inedible Kerandang fish (Channa pleurophthalmus Blkr) body parts and potential antiallergenic properties
}

\author{
Aryani Aryani1 (iD, Eddy Suprayitno², Bambang Budi Sasmito² and Hardoko Hardoko²
}

1. Doctoral Program, Faculty of Fisheries and Marine Sciences, Brawijaya University, Malang 65145, East Java, Indonesia; 2. Department of Fisheries Product Technology, Faculty of Fisheries and Marine Sciences, Brawijaya University, Malang 65145, East Java, Indonesia.

Corresponding author: Aryani Aryani, e-mail: aryani.binti69@gmail.com

Co-authors: ES: eddysuprayitno@ub.ac.id, BBS: niabbs@ub.ac.id, HH: hardoko@ub.ac.id

Received: 26-02-2020, Accepted: 05-06-2020, Published online: 30-07-2020

doi: www.doi.org/10.14202/vetworld.2020.1480-1486 How to cite this article: Aryani A, Suprayitno E, Sasmito BB, Hardoko H (2020) Characterization and identification of charcoal of inedible Kerandang fish (Channa pleurophthalmus $\mathrm{Bl}(\mathrm{kr})$ body parts and potential antiallergenic properties, Veterinary World, 13(7): 1480-1486.

\begin{abstract}
Background and Aim: The study about the antiallergenic properties of inedible fish body parts is still limited. Therefore, this study aimed to characterize the charcoal from the body parts of Kerandang fish (Channa pleurophthalmus Blkr) and identify its antiallergenic properties.

Materials and Methods: This study used some non-edible body parts extracted from the Kerandang fish (i.e., the scalp, scales, and dorsal, pectoral, ventral, anal, and caudal fins) using a maceration method with different solvents (ethanol, ethyl acetate, and chloroform). The identification of active compounds in the extract was carried out using liquid chromatographyhigh-resolution mass spectrometry (LC-HRMS) analysis, while the antihyaluronidase activity was determined using the antihyaluronidase test. The highest charcoal antihyaluronidase activity-extract was applied to ovalbumin-induced mice for 7 days with various doses $(10,15$, and $20 \mathrm{mg} / \mathrm{kg})$. The specific immunoglobulin E (IgE) was measured using enzyme-linked immunosorbent assay on day 8.

Results: Our LC-HRMS analysis showed that the active compound of charcoal in the caudal fins of Kerandang fish was hexadecanamide. The highest inhibition $\left(\mathrm{IC}_{50}\right)$ of hyaluronidase was found in the ethyl acetate extract of fish caudal fins at a concentration of $4 \mathrm{mg} / \mathrm{mL}$. We found that $15 \mathrm{mg} / \mathrm{kg}$ body weight of charcoal of fish caudal fins suppressed IgE expression in male mice.
\end{abstract}

Conclusion: Our findings indicate that the charcoal of non-edible body parts of Kerandang and one of its constituent, hexadecanamide, may have strong antiallergic effects.

Keywords: anti-allergy, charcoal, hyaluronidase, Kerandang fish.

\section{Introduction}

Many natural resources in Indonesia that are used in traditional medicine are now being studied for their potential application to the development of modern public health. However, despite the advancements of modern medicine and technology, traditional medicine remains a key component of public health in Indonesia, one that the government is still actively promoting [1]. The use of natural ingredients is advantageous compared to modern therapies; with only minimal side effects, natural materials are considered to be relatively safer than chemicals or synthetics on the market [2]. Allergy medication, for instance, is mostly reliant on synthetic drugs, such as antihistamines ( $\mathrm{AH})$, which have undesirable side effects. In an effort to minimize these unwanted side

Copyright: Aryani, et al. Open Access. This article is distributed under the terms of the Creative Commons Attribution 4.0 International License (http://creativecommons.org/licenses/by/4.0/), which permits unrestricted use, distribution, and reproduction in any medium, provided you give appropriate credit to the original author(s) and the source, provide a link to the Creative Commons license, and indicate if changes were made. The Creative Commons Public Domain Dedication waiver (http://creativecommons.org/ publicdomain/zero/1.0/) applies to the data made available in this article, unless otherwise stated. effects, people are starting to turn to more natural treatments. An allergic reaction or so-called hypersensitivity is an unnatural immunologic reaction in someone who has previously been sensitized with an antigen that causes an excessive immune reaction, which can manifest itself as inflammation or tissue damage. Rapid allergic reactions (i.e., anaphylactic reactions) are mainly mediated by immunoglobulin $\mathrm{E}(\mathrm{IgE})$. This reaction is characterized by a sudden response that occurs within minutes after the body is exposed to a source of antigens, thereby releasing mediators present in cells such as histamine, bradykinin, arachidonic acid, and prostaglandins. The release of these mediators causes allergic rhinitis, asthma, atopic dermatitis, skin flushing, and shortness of breath [3-6].

Allergens can be in the form of dust particles, plant dust, drugs, or food. The allergic mechanism is controlled by mast cells: When exposed to the allergen, they release the $\operatorname{IgE}$ antibody. $\operatorname{IgE}$ is also produced in large quantities when allergens attach to B lymphocyte cells $[7,8]$. The release of IgE then triggers degranulation and stimulates the release of histamine, leukotrienes, and other immune mediators, which triggers 
an allergic reaction. Like other immunoglobulins, $\operatorname{IgE}$ is produced by B- and plasma cells in response to an antigenic stimulus. The presence of interleukin (IL)-4 and IL-13 induces immunoglobulin class switching from other isotypes to IgE [9-11]. These two cytokines interact with receptors on the surface of B-cells to initiate a signaling cascade mediated by Janus kinase 3 and signal transducer and activator of transcription 6 . A second signal is required for class switching to $\operatorname{IgE}$ to occur, and this involves CD40 on the B-cell interacting with the CD40 ligand on the T-cell. Once IgE is produced by allergen-specific B-cells, it is released into the circulation [12-14].

The Kerandang fish has recently gained significant attention in Central Kalimantan, as charcoal can be made from several of the inedible body parts of the fish, then used as a traditional medicine to treat hereditary allergic reactions. The body parts of the fish are burned into charcoal, and then smeared on itchy skin or on the bumps that arise on the skin after an allergic reaction. Many fish that inhabit peatlands possess various bioactive materials, which can be used for several medicinal purposes [15].

Thus far, the antiallergenic properties of charcoal from the Kerandang fish have not been studied. In this study, we attempt to characterize charcoal from the body parts of Kerandang fish (Channa pleurophthal$m u s$ Blkr) and identify its antiallergenic properties.

\section{Materials and Methods}

\section{Ethical approval}

This study was approved by Animal Care and Use Committee, Brawijaya University, Indonesia (approval no. 1075-KEP-UB).

\section{Study period}

This study was conducted from September 2018 to September 2019. We obtained inedible parts of Kerandang fish, including the scalp, scales, dorsal fins, pectoral fins, ventral fins, anal fins, and caudal fins, from fishermen in Sebangau Kereng Bengkirai Lake, Central Kalimantan, Indonesia.

\section{Sample preparation}

The fish samples were cleaned and dried for 2-3 days, then burned to charcoal using a normal oven with a maximum temperature of $200^{\circ} \mathrm{C}$, until the resulting charcoal attained a mass of $500 \mathrm{~g}$ per sample. The extraction was done at a temperature of $<4^{\circ} \mathrm{C}$, using ethanol, ethyl acetate, and chloroform solvent, under the following protocol: $100 \mathrm{~g}$ of dry samples were added $500 \mathrm{~mL}$ of solvent, incubated for $24 \mathrm{~h}$, and filtered through a vacuum filter. The filtrate was dried using a vacuum rotary evaporator. The crude extract was stored until further analysis [16].

\section{Liquid chromatography-high-resolution mass spectrometry (LC-HRMS) \\ Each extract was diluted in a solvent until reach- ing a volume of $1300 \mu \mathrm{L}$. All extracts were spun for $2 \mathrm{~min}$ and filtered using a $0.22 \mu \mathrm{m}$ syringe filter.}

The samples were then inserted into the autosampler and injected into the LC-HRMS. The data were converted into a NetCDF format to ease data processing using mzCloud ${ }^{\mathrm{TM}}$ (HighChem LLC, Slovakia). MzCloud data processing consists of several steps, i.e., creating a chromatogram, reducing noise, identification based on molecular weight, and compiling data [17].

\section{In vitro antihyaluronidase test}

The antihyaluronidase activity was examined with a slight modification from the original protocol $[18,19]$. The sample solution $(1,2$, and $4 \mathrm{mg} / \mathrm{mL})$ was dissolved in a mixed solvent $(5 \%$ dimethyl sulfoxide in ethanol), while $50 \mu \mathrm{L}$ bovine hyaluronidase (7900 units $/ \mathrm{mL}$ ) was dissolved in $0.1 \mathrm{M}$ acetate buffer ( $\mathrm{pH} 3.5$ ), mixed with $100 \mu \mathrm{L}$ of each sample solution, then incubated for $20 \mathrm{~min}$ at $37^{\circ} \mathrm{C}$. Next, $100 \mu \mathrm{L}$ of $12.5 \mathrm{mM}$ calcium chloride was added to the reaction mixture and incubated for $20 \mathrm{~min}$ at $37^{\circ} \mathrm{C}$. Bovine hyaluronidase activated by $\mathrm{Ca}^{2+}$ was reacted with $250 \mu \mathrm{L}$ sodium hyaluronate $(1.2 \mathrm{mg} / \mathrm{mL})$ dissolved in $0.1 \mathrm{M}$ acetate buffer (pH 3.5), then incubated at $37^{\circ} \mathrm{C}$ for $40 \mathrm{~min}$. Next, $100 \mu \mathrm{L}$ of $0.4 \mathrm{M}$ sodium hydroxide and $100 \mu \mathrm{L}$ of $0.4 \mathrm{M}$ potassium borate were added to the reaction mixture and incubated in a bath of boiling water for $3 \mathrm{~min}$. After cooling at room temperature, $1.5 \mu \mathrm{L}$ of dimethylaminobenzaldehyde (DMAB) (4 g DMAB dissolved in $350 \mu \mathrm{L}$ of $100 \%$ acetic acid and $50 \mu \mathrm{L}$ of $10 \mathrm{M}$ hydrochloric acid) was added to the reaction mixture, then incubated at $37^{\circ} \mathrm{C}$ for $20 \mathrm{~min}$. Optical density (OD) in the reaction mixture was measured using a spectrophotometer at $585 \mathrm{~nm}$. The percentage of inhibition was calculated using the following equation:

$$
\% \text { Inhibitors }=[(\mathrm{ODc}-\mathrm{ODs}) / \mathrm{ODc}] \times 100
$$

Note: ODc is the OD of the control, ODs is the OD of the sample being tested. $\mathrm{IC}_{50}$ values causing $50 \%$ inhibition were determined using a linear regression analysis.

\section{In vivo IgE test}

The highest charcoal antihyaluronidase activity was applied topically as a cream to ovalbumin (OVA)-induced allergy mouse for 7 days at three different treatment doses $(10,15$, and $20 \mathrm{mg} / \mathrm{kg}$ ); hydrocortisone cream was used as a positive control. The specific IgE was measured on day 8 after the application by collecting the blood serum using the Mouse OVA sIgE enzyme-linked immunosorbent assay marker kit.

\section{Statistical analysis}

Data from the antihyaluronidase test and specific $\operatorname{IgE}$ levels were analyzed using a one-way analysis of variance using SPSS 23.0. LC-HRMS qualitative analyzed according to database mzCloud and compared with PubChem, Lipinski, and SwissADME bioinformatic method. 


\section{Results and Discussion}

\section{Antihyaluronidase test}

We measure the inhibition of hyaluronidase using charcoal extracts from inedible parts of the Kerandang fish body (Figure-1). The highest inhibition level was found in the caudal fins charcoal extract ( $966.33 \pm 66.06 \mathrm{mg} / \mathrm{mL})$, while the lowest was in pectoral fins charcoal extract $(213.96 \pm 66.06 \mathrm{mg} / \mathrm{mL})$. Figure- 2 shows that the $\mathrm{IC}_{50}$ value for the seven types of charcoal tested with three different solvents (chloroform, ethanol, and ethyl acetate). Data of $\mathrm{IC}_{50}$ of hyaluronidase activity were obtained from a linear regression analysis. $\mathrm{IC}_{50}$ values represent the extract concentration of samples needed to inhibit $50 \%$ of hyaluronidase activity, which determined by linear regression analysis [16]. The highest antihyaluronidase activity was found in caudal fins extracted with $4 \mathrm{mg} / \mathrm{mL}$ of ethyl acetate. This extract inhibited $50 \%$ of hyaluronidase activity at a concentration of 0.06 $\mathrm{mg} / \mathrm{mL}$. The lowest activity of antihyaluronidase was found in charcoal from Kerandang fish pectoral fins, which were extracted with $4 \mathrm{mg} / \mathrm{mL}$ chloroform (28.6 mg/mL) (Figure-2). Hyaluronidase is one of the essential enzymes involved in allergic and inflammatory reactions, playing a key role in mast cell degranulation [20-22]. This enzyme is also involved in the cancer migration, inflammation, and increased vascular system permeability in the extracellular matrix of connective tissues, affecting both organs (testes, spleen, skin, eyes, liver, kidneys, uterus, and placenta) and body fluids (tears, blood, and sperm) [23-25]. A previous study reported that hypo-allergies and anti-inflammatories were strong inhibitors of hyaluronidase activity [22], which led researchers to use hyaluronidase inhibitory activity as one of the parameters of hypo-allergenic testing [26,27].

\section{IgE levels}

The IgE levels in male mice were increased after sensitization OVA (Table-1), which indicated an allergic reaction had occurred. The IgE levels in the bloodstream were very small, usually $<1 \mathrm{U} / \mathrm{mL}$ ( $1 \mathrm{U}=2.4$ $\mathrm{ng})$. IgE levels in normal individual serum ranged from 0.1 to $0.4 \mu \mathrm{g} / \mathrm{mL}$. Individual IgE levels below $48 \mathrm{ng} / \mathrm{mL}$ are counter indicative of an allergic reaction, while $\mathrm{IgE}$ levels above $240 \mathrm{ng} / \mathrm{mL}$ indicate an allergy reaction [5]. Skin allergies are also induced by allergens, causing red, bumpy, scaly, itchy, or swollen skin. There are various types of allergies due to skin flora, culture, and diversity [27-29]. Understanding the role of $\mathrm{IgE}$ in allergic reactions has been a central part of research in this field.

The average level of $\mathrm{IgE}$ in control mice was $404.63 \pm 4.57 \mathrm{ng} / \mathrm{mL}$ (Figure-3). In the group given

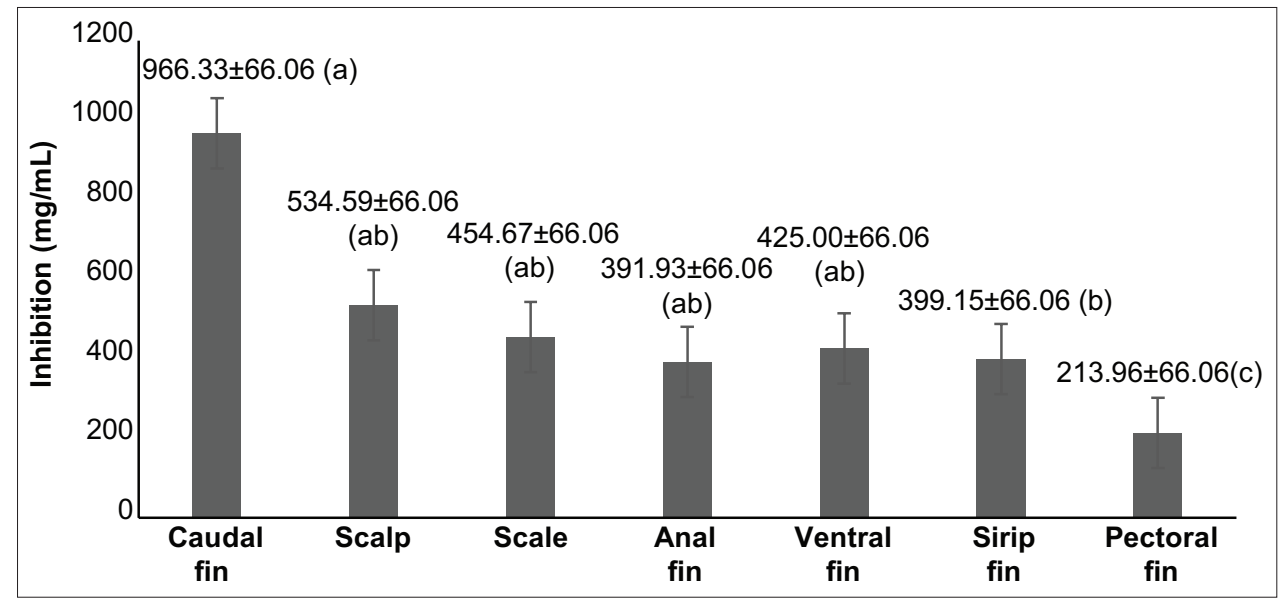

Figure-1: Hyaluronidase inhibition of charcoal extracts from several body parts of Kerandang fish that is not eaten.

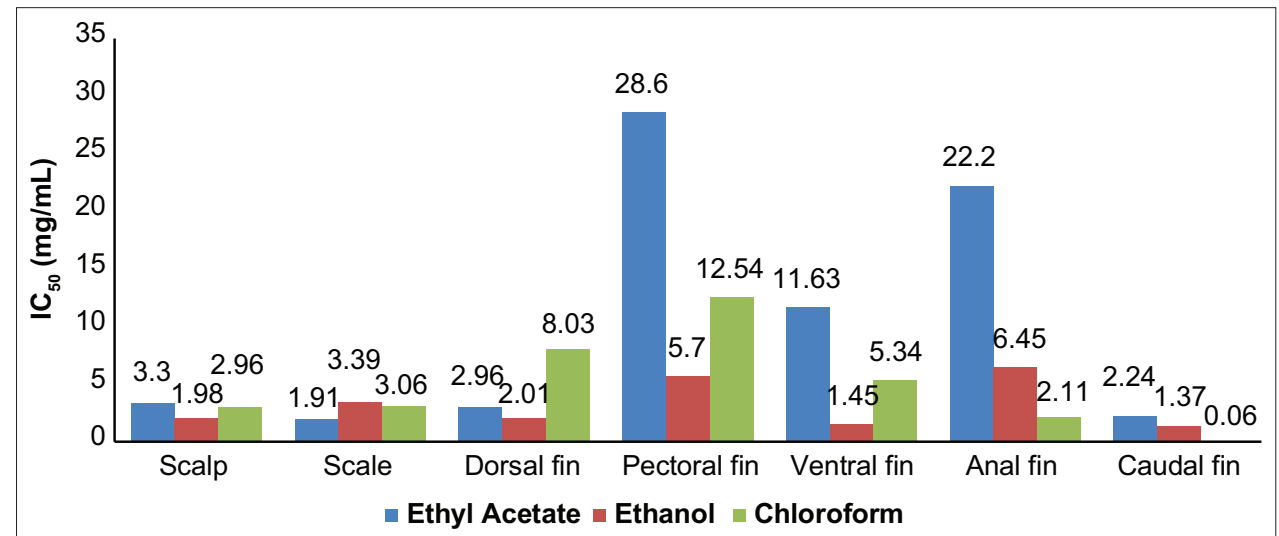

Figure-2: The antihyaluronidase activity $\left(\mathrm{IC}_{50}\right)$ of charcoal extract of fish body that is not eaten at different solvent. 


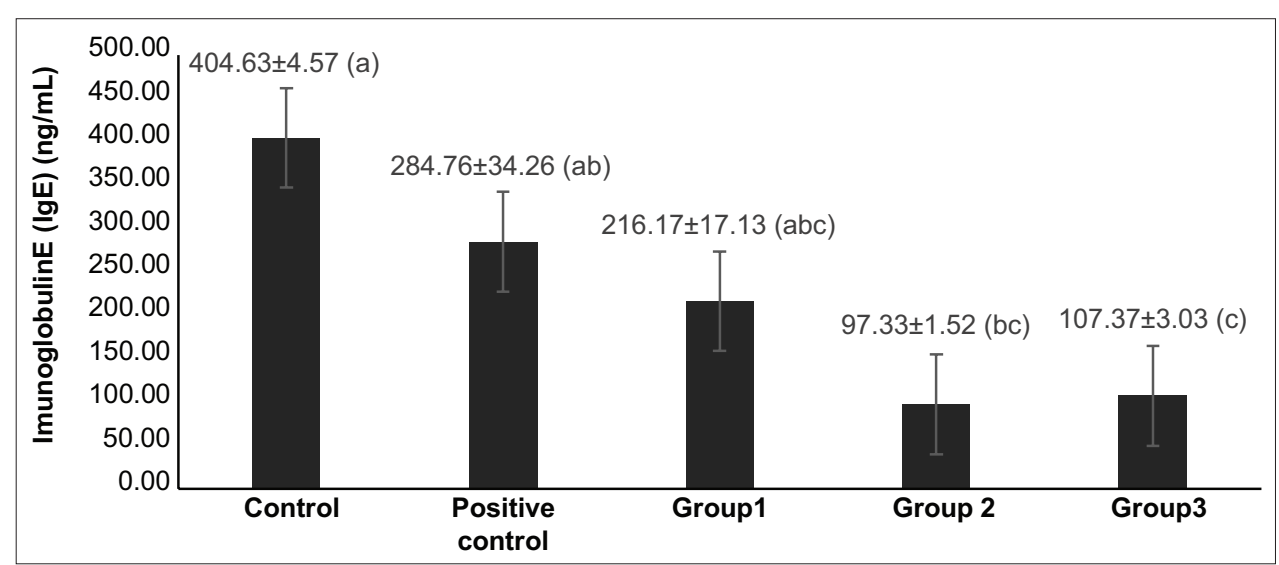

Figure-3: Specific immunoglobulin E levels in male mouse group after giving charcoal doses from Kerandang fish caudal fins. Note: Control: Mice without treatment; Positive control group: hydrocortisone cream; Group 1: Charcoal dose group of $10 \mathrm{mg} / \mathrm{kg}$ body weight (BW); Group 2: Charcoal dose group as much as $15 \mathrm{mg} / \mathrm{kg}$ BW; Group 3: Charcoal dose group as much as $20 \mathrm{mg} / \mathrm{kg} \mathrm{BW}$.

Table-1: IgE specific results on male mouse group before sensitization ovalbumin and after sensitization ovalbumin.

\begin{tabular}{lcc}
\hline Group & \multicolumn{2}{c}{ Result specific IgE (ng/ mL) } \\
\cline { 2 - 3 } & Pre-sensitization & After sensitization \\
\hline I & 95.7 & 434.6 \\
& 91.2 & 412.3 \\
II & 89.9 & 430.9 \\
& 92.1 & 591.2 \\
& 101.1 & 475.8 \\
III & 98.7 & 466.6 \\
& 102.3 & 1121.8 \\
& 99.1 & 908.7 \\
IV & 102.3 & 1147.7 \\
& 99.2 & 647.3 \\
& 112.4 & 789.6 \\
V & 90.9 & 709.4 \\
& 96.7 & 749.1 \\
& 102.9 & 736.2 \\
& 92.9 & 549.9 \\
\hline
\end{tabular}

Group I=Negative control group, Group II=Positive control group, Group III=Treatment 1 group, Group IV=Treatment 2 group, Group V=Treatment 3 group, IgE: Immunoglobulin $\mathrm{E}$

hydrocortisone cream, the average specific $\operatorname{lgE}$ level was $284.76 \pm 34.26 \mathrm{ng} / \mathrm{mL}$. The group given a charcoal dose of $10 \mathrm{mg} / \mathrm{kg}$ body weight (BW) (Group 1) had an average specific level of IgE of $216.17 \pm 17.13 \mathrm{ng} / \mathrm{mL}$. Group 2 was given a charcoal dose of $15 \mathrm{mg} / \mathrm{kg} \mathrm{BW}$ and had an average specific IgE level of $97.33 \pm 1.52 \mathrm{ng} / \mathrm{mL}$, while Group 3 received a dose of $20 \mathrm{mg} / \mathrm{kg}$ BW had an average level $107.37 \pm 3.0 \mathrm{ng} / \mathrm{mL}$. Of the five treatment groups, Group 2 had the lowest average specific IgE level, suggesting that the treatment dose was able to reduce specific IgE levels in the blood of male mice, while the control group had the highest level of specific IgE, suggesting the control group did not decrease IgE levels. In the three treatment groups with tail fin charcoal doses, the group treated with $15 \mathrm{mg} / \mathrm{kg} \mathrm{BW}$ had the lowest average specific $\operatorname{lgE}$ level, while 10 $\mathrm{mg} / \mathrm{kg} \mathrm{BW}$ induced the highest average specific $\operatorname{lgE}$ levels. This result suggests that the treatment of a 10 $\mathrm{mg} / \mathrm{kg}$ BW dose did not significantly reduce IgE levels in male mice. The treatment that caused a significant impact was $15 \mathrm{mg} / \mathrm{kg} \mathrm{BW}$ dose (Group 2), which induced a decrease in IgE levels in male mice.

Histamine plays a key role in the pathogenesis of allergies through the regulation of differentiation of CD4+ Th-cell lymphocytes [30]. The mechanism through which $\mathrm{AH}$ operates is by blocking histamine receptors to incoming histamines or by expelling histamine already in the receptor [31]. By inhibiting mast cell degranulation, the secretion of vasoactive amines, such as histamine, lipid mediators, and cytokines playing a role in the inflammatory process in allergic reactions, is also reduced. AH have long been prescribed for atopic dermatitis as adjunctive therapy with topical agents that can block the action of histamines on the skin [32].

Topical nasal AHs such as azelastine are also available and recommended forrunny nose due to allergic effects. To increase the efficacy of oral AHs in allergic rhinitis for those who continue to exhibit symptoms, the preferred topical therapy is a corticosteroid nasal spray. These sprays should be considered a first-line treatment in moderate to severe allergic rhinitis $[33,34]$.

Treatment for allergic reactions takes several forms: One can increase $\operatorname{IgE}$ levels so incoming antigens can be destroyed through the complement system; others provide the patients with AHs, reduce IgE levels to inhibit the binding between antigens with $\mathrm{IgE}$, prevent the entry of antigens into the body, or again inhibit mastocyte degranulation to prevent the release of chemical mediators, which stimulate the allergic reaction [35-37]. In other cases, antiallergenic drugs work by inhibiting the degranulation of Rat Basophilic Leukemia-2H3 cells, using $\beta$-hexosaminidase as a biomarker, actinomycete Nesterenkonia flava, at the epidermis environment interface [38,39].

\section{LC-HRMS analysis}

The identification of charcoal ethyl acetate extract from Kerandang fish caudal fins using 
LC-HRMS is shown in Figure-4. The spectral results show that the ethyl acetate extract of the Kerandang fish caudal fins obtained eight peaks at a retention time of $1.06 ; 12.12 ; 12.64 ; 16.57 ; 17.74$; 18.08; 20.10, and $26.39 \mathrm{~min}$. LC-HRMS data were analyzed using the mzCloud MS/MS library data software and identification of the structure of chemical compounds detected in the LC-HRMS with the PubChem, Lipinski, and SwissADME online database. The ethyl acetate extract of charcoal made from Kerandang fish caudal fins analyzed using LC-HRMS Best Match produced 49 compounds, which were identified based on their mass spectrum and mzCloud values. The highest value recorded $(>90)$ was identified as the hexadecanamide compound. Hexadecanamide is a derivative of palmitic acid also found in palmitoylethanolamide (PEA). It is also sometimes referred to as n-(2-hydroxyethyl) hexadecanamide, n-hexadecanoylethanolamine, palmidrol PEA, palmitylethanolamide, PEA, n-(2-hydroxyethyl) hexadecanamide, or again n-(2-hydroxyethyl)-hexadecanamide palmid. The chemical formula for hexadecanamide formula is $\mathrm{C}_{16} \mathrm{H}_{33} \mathrm{NO}$ [39]. According to the Lipinski method, there are five criteria of drugs: Molecular mass $<500 \mathrm{Da}$, high lipophilicity $(\log \mathrm{P}<5),<5$ hydrogen bond donors, $<10$ hydrogen bond acceptors, and molar refractivity from 40 to $130 \mathrm{~m}^{3} \mathrm{~mol}^{-1}$ [40]. Comparison results based on 3D_CID conformer 3008318 PubChem on hexadecanamide compounds

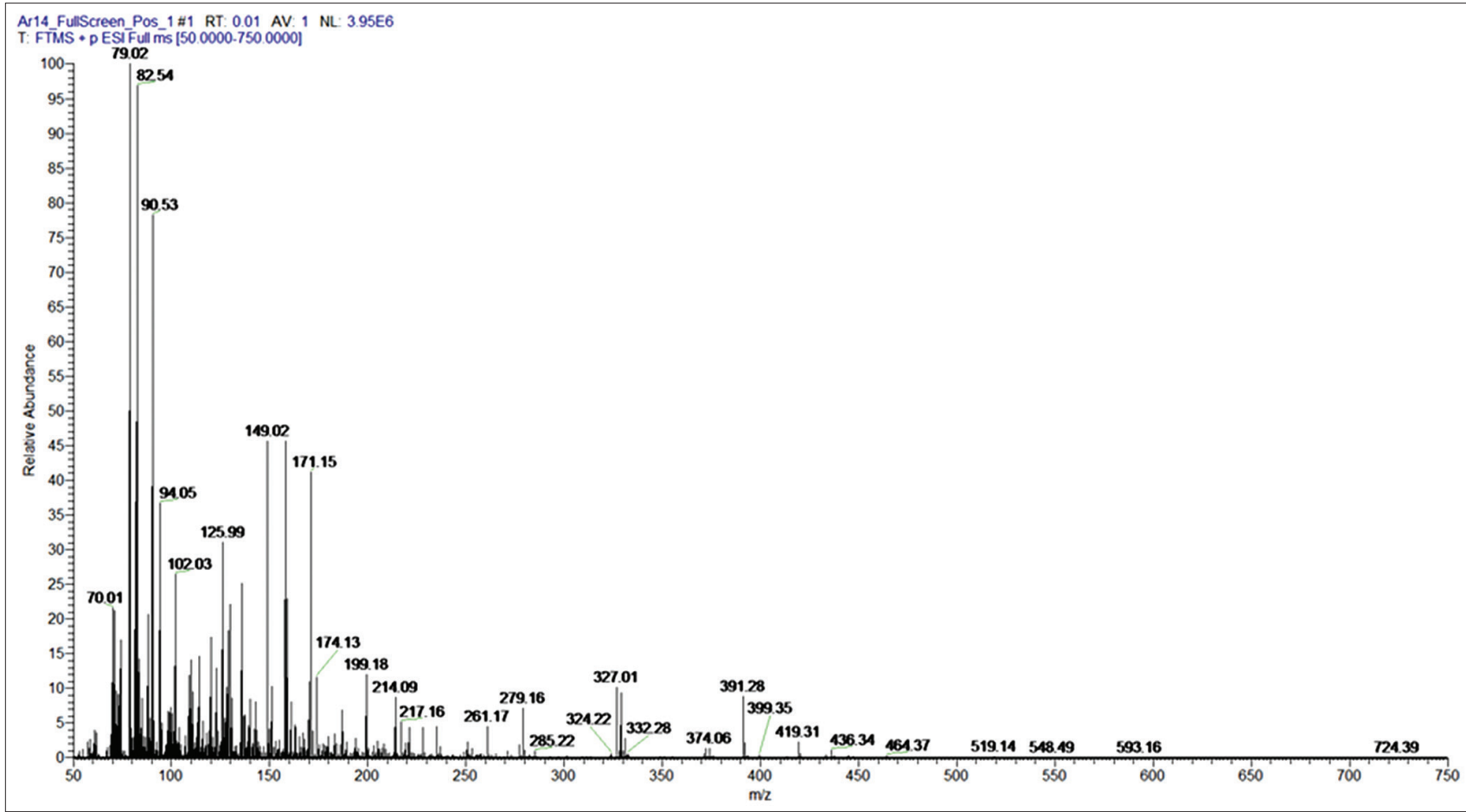

Figure-4: Liquid chromatography-high-resolution mass spectrometry chromatogram results.

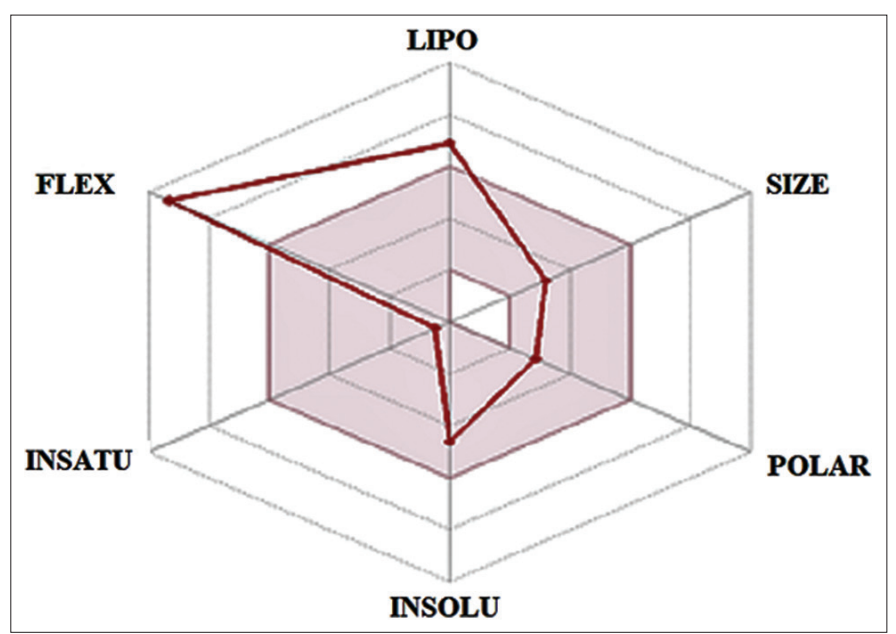

Figure-5: Screening availability hexadecanamide using SwissADME. The colored zone is the suitable physicochemical space for oral bioavailability. Notes: LIP (Lipophility): $-0.7<$ XLOGP3 < +50; SIZE: $150 \mathrm{~g} / \mathrm{mol}<\mathrm{MV}<500 \mathrm{~g} / \mathrm{mol}$; POLAR (Polarity): $20 \mathrm{~A}^{2}<$ TPSA < 130A2; INSOLU (insolubility): $0<$ Log 5 (ESOL) < 6; INSATU (Unsaturation): $0.25<$ Fraction Csp3 $<1$; FLEX (Flexibility): $0<$ Number rotatable bonds $<9$. 
are as follows: A molecular mass of 255.00 a $\log \mathrm{P}$ of 4.95 , two hydrogen bond donors, two hydrogen bond acceptors, and a molar reactivity of 79.51. Therefore, hexadecanamide meets all five drug criteria required by the Lipinski method. Hexadecanamide has been shown to have anti-inflammatory, anti-nociceptive, nervous, anticonvulsant, and antifungal properties [41-43]. Based on screening availability using SwissADME (Figure-5), it was suggested that hexadecanamide has a high potential as an anti-allergenic drug based on its bioavailability, lipophilicity, size, polarity, solubility, saturation, and flexibility.

\section{Conclusion}

Our findings indicate that the charcoal of non-edible body parts of Kerandang and one of its constituent, hexadecanamide, may have strong antiallergic effects. More methodological work is needed on how to determine the effect inedible Kerandang fish body part on other parameter related to skin allergy.

\section{Authors' Contributions}

AA designed the research and wrote the manuscript. ES helped in experimental method. BBS collected and analyzed the data and $\mathrm{HH}$ revised the manuscript. All authors read and approved the final manuscript.

\section{Acknowledgments}

The authors thank the Indonesian Ministry of Finance and Indonesian Ministry of Research and Higher Education for funding this research through LPDP BUDI-DN scholarship 2016 (grant no. 20161141031737).

\section{Competing Interests} interests.

The authors declare that they have no competing

\section{Publisher's Note}

Veterinary World remains neutral with regard to jurisdictional claims in published institutional affiliation.

\section{References}

1. Wijayakusuma, H.M.H. (1999) Medicinal Plants in Indonesia. Prestasi Insan Indonesia, Jakarta.

2. Semiawan, F.I., Ahmad, M.A. and Masruhim, M. (2015) Anti-inflammatory activity of leaf kerehau (Callicarpa longifolia L.) extract. J. Sci. Health, 1(1): 99-103.

3. Baratawidjaja, K.G. and Rengganis, I. (2014) Basic Immunology. University of Indonesia Press, Jakarta. p217-283.

4. Abbas, A., Lichtman, A.H. and Pillai, S. (2015) Basic Immunology: Functions and Disorders of the Immune System. Elsevier, Philadelphia, PA.

5. Kuby, J. (2007) Immunology. WH Freeman, New York.

6. Janeway, C.A., Travers, P., Walport, M. and Shlomchik, M.J. (2001) The Immune System in Health and Disease. $5^{\text {th }}$ ed. Garland Science, New York.

7. Potaczek, D.P. (2014) Links between allergy and cardiovascular or hemostatic system. Int. J. Cardiol., 170(3): $278-285$.
8. Molderings, G.J., Stefan, B., Jurgen, H. and Lawrence, B.A. (2011) Mast cell activation disease: A concise practical guide for diagnostic workup and therapeutic options. $J$. Hematol. Oncol., 4(10): 1-8.

9. Kelly, B.T. and Grayson, M.H. (2016) Immunoglobulin E, what is it good for? Ann. Allergy Asthma Immunol., 116(3): 183-187.

10. Amarasekera, M. (2011) Immunoglobulin E in health and disease. Asia Pac. Allergy, 1(1): 12-15.

11. Dehlink, E., Baker, A.H., Yen, E., Nurko, S. and Fiebiger, E. (2010) Relationships between levels of serum IgE, cellbound $\operatorname{IgE}$, and IgE-receptors on peripheral blood cells in a pediatric population. PLoS One, 5(8): 12204.

12. Xu, Z., Wang, T., Guo, X., Li, Y., Hu, Y., Ma, C. and Wang, J. (2018) The relationship of serum antigen-specific and total immunoglobulin E with adult cardiovascular diseases. Int. J. Med. Sci., 15(11): 1098-1104.

13. Guo, X., Yuan, S., Liu, Y., Zeng, Y., Xie, H., Liu, Z., Zhang, S., Fang, Q., Wang, J. and Shen, Z. (2016) Serum IgE levels are associated with coronary artery disease severity. Atherosclerosis, 251(2016): 355-360.

14. Wang, J., Cheng, X. and Xiang, M.X. (2011) IgE stimulates human and mouse arterial cell apoptosis and cytokine expression and promotes atherogenesis in Apoe-/-mouse. $J$. Clin. Invest., 121(9): 3564-3577.

15. Liu, W.T., Li, G.Y., Miao, Y.Q. and Wu, X.H. (2009) Preparation and characterization of pepsin-solubilized Type I collagen from the scales of snakehead (Ophiocephalus argus). J. Food Biochem., 33(1): 20-37.

16. Kakegawa, H., Matsumoto, H. and Satoh, T. (1984) Activation of hyaluronidase by metallic salts and compound $40 / 80$, and inhibitory effect of anti-allergic agents on hyaluronidase. Chem. Pharm. Bull., 33(2): 642-646.

17. Lu, D., Xue, L., Feng, C., Jin, Y., Wu, C., Xie, C., Gonzalez, F.J., Wang, G. andZhou, Z. (2019) A systemic workflow for profiling metabolome and lipidome in tissue. J. Chromatogr. A, 1589(2019): 105-115.

18. Lee, K.K. and Choi, J.D. (1999) The effects of Areca cate$c h u \mathrm{~L}$ extract on antiinflammation and anti-melanogenesis. Int. J. Cosmet. Sci., 21(4): 275-284.

19. Rini, P., Ohtani, Y. and Ichiura, H. (2012) Antioxidant, anti-hyaluronidase and antifungal activities of Melaleuca leucadendron Linn. leaf oils. J. Wood Sci., 58(5): 429-443.

20. Menzel, E.J. and Farr, C. (1998) Hyaluronidase and its substrate hyaluronan: Biochemistry, biological activities and therapeutic uses. Cancer Lett., 131(1): 3-11.

21. Shibata, T., Fujimoto, K., Nagayama, K., Yamaguchi, K. and Nakamura, T. (2002) Inhibitory activity of brown algae phlorotannins against hyaluronidase. Int. J. Food Sci. Technol., 37(6): 703-770.

22. Fujitani, N., Sakaki, S., Yamaguchi, Y. and Takenaka, H. (2001) Inhibitory effects of microalgae on the activation of hyaluronidase. J. Appl. Phycol., 13(2001): 489-492.

23. Mio, K. and Stern, R. (2002) Inhibitors of the hyaluronidases. Matr. Biol., 21(1): 31-37.

24. Suzuki, K., Terasaki, Y. and Uyeda, M. (2002) Inhibition of hyaluronidases and chondroitinases by fatty acids. $J$. Enzyme Inhib. Med. Chem., 17(3): 183-186.

25. Meisarani, A. and Ramadhania, Z.M. (2016) The content of chemical compounds and bioactivity Melaleuca leucadendron Linn. Farm. Suppl., 14(2): 123-144.

26. Harunari, E., Imad, C., Igarashi, Y., Fukuda, T., Terahara, T. and Kobayashi, T. (2015) Isolation and characterization of a novel hyaluronidase inhibitor from a marine Actinomycetes Strain. KnE Life Sci., 1(2013): 114-119.

27. Mukesi, M., Phillipus, I.N., Moyo, S.R., Mtambo, O.P. (2018) Prevalence of skin allergies in adolescents in Namibia. Int. J. Aller. Med., 3(1): 22.

28. Lowe, A.J, Leung, D.Y.M., Tang, M.L.K., Su, J.C. and Allen, K.J. (2018) The skin as a target for prevention of the atopic march. Ann. Allergy Asthma Immunol., 120(2): $145-151$. 
29. Knowles, S., Binkley, K., Keith, P., Knowles, H. and Guyatt, G. (2016) Skin testing for allergic rhinitis: A health technology assessment. Ont. Health Technol. Assess. Ser., 16(10): 1-45.

30. Criado, P.R., Criado, R.F.J., Maruta, C.W. and Machado F.C.A. (2010) Histamine, histamine receptors and antihistamines: New concepts. Ann. Bras. Dermatol., 85(2): 195-210.

31. Thangam, E.B., Jemima, E.A., Singh, H., Baig, M.S., Khan, M., Mathias, C.B. and Saluja, R. (2018) The role of histamine and histamine receptors in mast cell-mediated allergy and inflammation: The hunt for new therapeutic targets. Front. Immunol., 9(1873); 1-9.

32. Randall, K.L. and Hawkins, C.A. (2018) Antihistamines and allergy. Austr. Prescr, 41(2): 41-45.

33. Tamura, T., Matsubara, M., Takada, C., Hasegawa, K., Suzuki, K., Ohmori, K. and Karasawa, A. (2004) Effects of olopatadine hydrochloride, an antihistamine drug, on skin inflammation induced by repeated topical application of oxazolone in mouse. Br. J. Dermatol., 151(6): 1133-1142.

34. Thomas, S.H. (2012) Antihistamine poisoning. Medicine, 40(3): 109-110.

35. Chen, Y., Lin, H. and Li, Z. (2015) The anti-allergic activity of polyphenol extracted from five marine algae. J. Ocean. Univ. China, 14(2015): 681-684.

36. Grabowska, K., Podolaka, I., Galantya, A., MakowskaWąs, D.J., Sobolewska, D., Janeczkoa, Z. and Żmudzki, P. (2015) In vitro anti-denaturation and antihyaluronidase activities of extracts and galactolipids from leaves of Impatiens parviflora DC. Nat. Prod. Res., 30(10): 1219-1223.

37. Olorunnisola, O.S, Adetutu, A. and Fadahunsi, O.S. (2017) Anti-allergy potential and possible modes of action of Sphenocentrum jollyanum pierre fruit extracts. $J$. Phytopharmacol., 6(1): 20-26.

38. Xie, C., Liu, Q., Xia, J.M., Gao, Y., Yang, Q., Shao, Z., Liu, G. and Yang, X. (2017) Anti-allergic compounds from the deep-sea-derived actinomycete Nesterenkonia flava MCCC 1K00610. Mar. Drugs., 15(3): 1-8.

39. Mihaela, H., Radu, C., Ferri, A., Grigoriu, A. and Oproiu, L. (2013) Anti-allergic cellulose support at the epidermis-environment interface. Cellulose Chem. Technol., 47(3-4): 257-266.

40. Benet, L.Z., Hosey, C.M., Ursu, O. and Oprea T.I. (2016) BDDCS, the Rule of 5 and drugability. Adv. Drug Deliv. Rev., 101(2016): 89-98.

41. Bacci, C., Cassetta, G., Emanuele, B. and Berengo, M. (2011) Randomized split-mouth study on postoperative effects of palmitoylethanolamide for impacted lower third molar surgery. Int. Schol. Res. Net., 2011(2011): 1-6.

42. Al-Rubaye, A.F., Kaizal, A.F. and Hameed, I.H. (2017) Phytochemical screening of methanolic leaves extract of Malva sylvestris. Int. J. Pharmacogn. Phytochem. Res., 9(4): 537-552.

43. Rahbar, N., Shafaghat,A. and Salimi, F. (2012)Antimicrobial activity and constituents of the hexane extracts from leaf and stem of Origanum vulgare L. ssp. Viride (Boiss) Hayek. Growing wild in Northwest Iran. J. Med. Plant Res., 6(13): 2681-2685. 